University of Nebraska - Lincoln

DigitalCommons@University of Nebraska - Lincoln

USGS Staff -- Published Research

US Geological Survey

2005

Late-Holocene flooding and drought in the Northern Great Plains, USA, reconstructed from tree rings, lake sediments and ancient shorelines

M.D. Shapley

University of Minnesota, shap0029@umn.edu

W. C. Johnson

South Dakota State University, carter.johnson@sdstate.edu

D. R. Engstrom

Science Museum of Minnesota

W. R. Osterkamp

US Geological Survey

Follow this and additional works at: http://digitalcommons.unl.edu/usgsstaffpub

Part of the Geology Commons, Oceanography and Atmospheric Sciences and Meteorology Commons, Other Earth Sciences Commons, and the Other Environmental Sciences Commons

Shapley, M. D.; Johnson, W. C.; Engstrom, D. R.; and Osterkamp, W. R., "Late-Holocene flooding and drought in the Northern Great Plains, USA, reconstructed from tree rings, lake sediments and ancient shorelines" (2005). USGS Staff -- Published Research. 899. http:// digitalcommons.unl.edu/usgsstaffpub/899

This Article is brought to you for free and open access by the US Geological Survey at DigitalCommons@University of Nebraska - Lincoln. It has been accepted for inclusion in USGS Staff -- Published Research by an authorized administrator of DigitalCommons@University of Nebraska - Lincoln. 


\title{
Late-Holocene flooding and drought in the Northern Great Plains, USA, reconstructed from tree rings, lake sediments and ancient shorelines
}

\author{
M.D. Shapley, ${ }^{*}$ W.C. Johnson, ${ }^{2}$ D.R. Engstrom ${ }^{3}$ \\ and W.R. Osterkamp ${ }^{4}$
}

$\left({ }^{1}\right.$ Limnological Research Center, University of Minnesota, Minneapolis, MN 55455, USA; ${ }^{2}$ Department of Horticulture, Forestry, Landscape, and Parks, South Dakota State University, Brookings, SD 57007, USA;

${ }^{3}$ St Croix Watershed Research Center, Science Museum of Minnesota, Marine on St Croix, MN 55047, USA $;{ }^{4}$ US Geological Survey - Water Resources Division, Desert Research Laboratory, Tucson, AZ 85745, USA)

Received 3 March 2003; revised manuscript accepted 18 March 2004

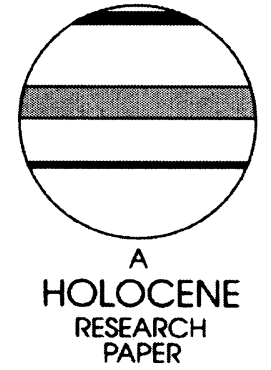

PAPER

\begin{abstract}
During the AD 1990s the Waubay Lakes complex in eastern South Dakota experienced historically unprecedented high water levels. Property damage from this flooding led to an examination of the occurrence of past pluvial episodes and their relation to climate. A 1000-year hydroclimate reconstruction was developed from local bur oak (Quercus macrocarpa) tree-ring records and lake-sediment cores. Analysis of lake shoreline and drainage features provides late-Quaternary geomorphic context for this high-resolution record. Tree-ring width and shell geochemistry of the ostracode Candona rawsoni show marked coherence, indicating synchronous responses to moisture balance in vegetation and lake salinity; geomorphic evidence suggests buffering of lake-system expansion during pluvial periods by evaporative dynamics. Pluvial periods display a recurrence frequency of approximately 140-160 years over the past millennium. Prior to AD 1800, both lake highstands and droughts tended towards greater persistence than during the past two centuries. Frequency and timing of hydroclimatic oscillations show strong similarities to records from other sites in the Northern Great Plains (NGP) of North and South Dakota, and incomplete coherence with records of southern Manitoba.
\end{abstract}

Key words: Great Plains palaeoclimate, tree rings, Quercus macrocarpa, ostracode geochemistry, Candona rawsoni, shoreline geomorphology, floods, drought, Waubay Lakes, South Dakota.

\section{Introduction}

Broad areas of the North American northern Great Plains (NGP) have experienced notable lake highstands since the early 1990s. Among the areas most affected has been the Waubay Lake complex, located in eastern South Dakota (Figure 1). During lake lowstands, the Waubay complex consists of eight basins separated by low divides. During the recent highstand, the upper lakes coalesced and began spilling to Bitter Lake, the lowest (currently terminal) basin in the complex. Waubay Lake rose by $5.7 \mathrm{~m}$ and more than doubled in area from 1993 to 1999 . Severe flooding of roads, farms and towns led the Federal Emergency Management Agency (FEMA) to declare the Waubay region a disaster area on 1 June 1998 (Niehus et al., 1999a). Other closed-basin lakes in the NGP have flooded during this climatic extreme, notably Devils Lake in North Dakota which rose over $5 \mathrm{~m}$ between 1990 and 1997 causing considerable economic damage (Wiche et al., 1997; Winter and Rosenberry, 1998).

Rising lake levels were caused by a combination of aboveaverage precipitation and below-average air temperatures. Annual precipitation at Webster, South Dakota, averaged $69.6 \mathrm{~cm}$ between 1991 and 1998, $16.0 \mathrm{~cm}$ above the 1960-90 average (NGPWRRC, 1999). Relatively cool, humid air 


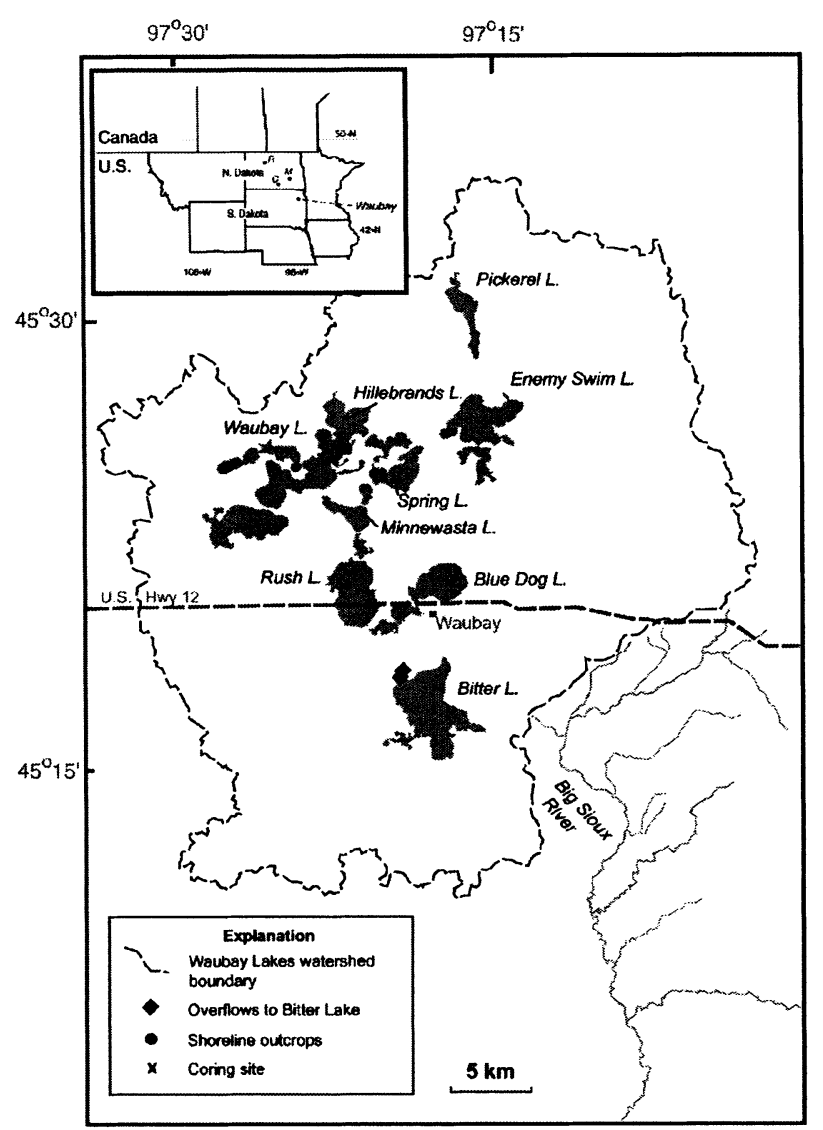

Figure 1 Study sites and location map of the Waubay Lake system. Letters (inset) correspond to regional lacustrine palaeorecords: $\mathrm{C}=$ Coldwater Lake; $\mathrm{M}=$ Moon Lake; $\mathrm{R}=$ Rice Lake.

reduced evaporation during the 1991-98 period and contributed to $225.8 \mathrm{~cm}$ of land-surface hydrologic loading (difference between evaporation and precipitation) (NGPWRRC, 1999); mean annual potential evaporation exceeds precipitation in this region.

A comprehensive, interdisciplinary study was initiated shortly after the FEMA disaster declaration to determine the historical context of the rising lake levels, estimate the time expected to return to accustomed levels, and explore mitigation alternatives. Here we report our use of palaeoecological and geomorphological methods to reconstruct the climate and lake-level history of the region. Three independent records of moisture balance in the Waubay Lake watershed are integrated into a composite history of recurrence frequency and duration of lake highstands during the past millennium. Tree-ring indices from living and preserved bur oak (Quercus macrocarpa) provide a 325-year record of moisture availability around Waubay Lake; shell geochemistry of the benthic ostracode Candona rawsoni provides a high-resolution 1000-year record of lake $\mathrm{Mg} / \mathrm{Ca}$, a reliable proxy for salinity in the NGP; and lake shoreline geomorphology constrains the upper bounds of lake elevation and the history of lake coalescence.

Environmental reconstructions for the Waubay system are placed in the context of previous palaeolimnological records from regional lakes, most notably Moon Lake (Laird et al., 1996; 1998) and Coldwater Lake (Fritz et al., 2000), both in southeastern North Dakota, and Rice Lake in north-central North Dakota (Fritz et al., 2000; Yu et al., 2002). Reconstructions from these lakes indicate that the last two millennia were hydrologically complex, with large oscillations between low-salinity wet phases and high-salinity dry phases. Although these shifts are broadly synchronous among sites, fine-scale differences occur in both timing and magnitude, due to uncertainties inherent in core chronology as well as site-specific differences in hydrochemical responses to climatic change. Additional well-constrained high-resolution records, such as presented here for the Waubay system, improve chronological reliability and help resolve local (lake-specific) responses and regional climate forcing in the NGP.

\section{Study area}

The Waubay Lake system is located on the Coteau des Prairies, a prominent highland in the eastern part of the NGP (Figure 1). Geologically the region is underlain by Cretaceous and Tertiary sedimentary units and is thickly blanketed by hummocky glacial drift. The climate is subhumid to semi-arid, with large seasonal temperature extremes and high interannual moisture variability reflecting the influences of contrasting regional air masses and a mid-continental location (Bryson and Hare, 1974). The natural vegetation is tall grass prairie, with deciduous forest in favorable settings. Principal tree species are bur oak (Quercus macrocarpa), green ash (Fraxinus pennsylvanica) and American elm (Ulmus americana). Much of the landscape is farmed and grazed.

The major basins that comprise the Waubay complex include North and South Waubay, Spring, Hillebrands and Minnewasta Lakes, all coalesced during the late 1990s, Blue Dog and Rush, which approached coalescence, and the terminal basin, Bitter Lake, which has received spillage from Rush Lake since the late 1990s (Figure 1). Any spill from Bitter Lake resulting from extended positive water balance would ultimately flow to the Big Sioux River, a tributary of the Missouri River. Natural spillway levels between these eight lakes range from 547 to $549 \mathrm{~m}$, the lowest being between Rush and Waubay Lakes. However, artificial barriers and conduits (e.g., roadways and ditches) have modified the routing of water between basins since European settlement. The Waubay complex is fed by surface and groundwater flow from two lakes in the upper part of the watershed, Pickerel and Enemy Swim.

Water levels and surface area of regional lakes have changed dramatically over the past one and a half centuries. Although the record is fragmentary, there is little doubt that levels of the late 1990s were the maximum for the period, while levels in the 1930s were the minimum. Lake levels were high during early European settlement, based on the General Land Office meander survey of 1868-77. Lakes at that time were similar in size to those indicated by LANDSAT images in 1994 (Table 1; Figure 2), just after the lakes began rising sharply from heavy rains in 1993. We estimate lake area for the Waubay system to have been 10300 ha in 1868-77 and 8550 ha in 1994 (Table 1). In contrast, several lakes were dry or nearly dry in 1939 when the first aerial photographs were taken (Figure 2). Total surface area of the lakes after the 1930s drought was about one-third of that in 1868-77 (Table 1). Lake levels probably were lower earlier at the height of the drought. Bitter Lake was dry in 1934 (Rothrock, 1935). Systematic measurements of Waubay Lake indicate relatively stable levels from the early 1960s until 1993. Between 1993 and 1998, Waubay Lake rose by about $5.7 \mathrm{~m}$. Total lake area in 1998 was 13433 ha, 3.5 times the surface area in 1939, and 1.3 times the area in $1868-77$ (Table 1).

The instrumental record of moisture balance in this region is summarized by the monthly Palmer Hydrologic Drought Index (PHDI) for northeastern South Dakota (Figure 3). The PHDI incorporates precipitation, evaporation and soil moisture conditions into an index representing drought 
Table 1 Lake areas based on General Land Office meander survey, 1939 aerial photography, and 1994 and 1998 LANDSAT imagery

\begin{tabular}{|c|c|c|c|c|}
\hline Lake name & $\begin{array}{l}1868-1877 \\
\text { meander } \\
\text { survey } \\
\text { (hectares) }\end{array}$ & $\begin{array}{l}1939 \\
\text { aerial } \\
\text { photography } \\
\text { (hectares) }\end{array}$ & $\begin{array}{l}1994 \\
\text { LANDSAT } \\
\text { (hectares) }\end{array}$ & $\begin{array}{l}1998 \\
L A N D S A T \\
\text { (hectares) }\end{array}$ \\
\hline Pickerel & 437 & 398 & 370 & 406 \\
\hline North Waubay & 2926 & 622 & 2694 & 3759 \\
\hline Enemy Swim & 1166 & 652 & 844 & 1179 \\
\hline Hillebrands & 271 & 103 & 183 & 379 \\
\hline Spring & 477 & 257 & 379 & 523 \\
\hline Blue Dog & 624 & 572 & 587 & 625 \\
\hline Swan Pond & 64 & 0 & 43 & 82 \\
\hline South Waubay & 1292 & 123 & 1271 & 1934 \\
\hline Minnewasta & 222 & 16 & 234 & 260 \\
\hline Rush & 1145 & 43 & 63 & 1311 \\
\hline Bitter & 1717 & 923 & 1381 & 2976 \\
\hline Total & 10341 & 3709 & 8549 & 13434 \\
\hline
\end{tabular}

intensity relative to regional average conditions (Keyantash and Dracup, 2002; Alley, 1984); time series of PHDI show persistence of wet (positive index) and dry (negative index) conditions. Over the twentieth century, PHDI anomalies tend toward multiyear persistence in sign. The most notable anomalies correlate with lake level extremes of the 1930s and 1990s.

\section{Methods}

\section{Tree-ring records}

Prior to this study, northeastern South Dakota (SD) presented a large gap in the continent-wide tree-ring and palaeoclimate data base (Cook et al., 1996). The natural scarcity of trees in the central US grasslands and heavy timber exploitation during European settlement have left few living trees much older than meteorological records (approximately 100 years). To make up for the dearth of old trees from which to reconstruct palaeoclimates, the Laboratory of Tree-Ring Research (University of Arizona-Tucson) cored old timbers in Fort Sisseton in northeastern SD (Sieg and Meko, 1995). Two oak timbers were found which probably date back to the original construction about 1864 . Two cores were extracted from each timber in 1992. These cores were included in the Laboratory's data base, but no living trees of sufficient age in northeastern SD were found at the time to link with the Fort trees. Our goal was to find living trees that would overlap in date with the Fort cores. Beginning in autumn 1998, 45 trees (all but four of them bur oak, Quercus macrocarpa) were cored at five sites near Waubay Lake. Most (32) were collected on the islands of the Waubay Lake complex itself. Trees were cored at breast height, and the cores were returned to South Dakota State University for preparation and initial analysis.

The cores were mounted in wooden channels, filed flat, and sanded until the rings were clearly distinguishable (Stokes and

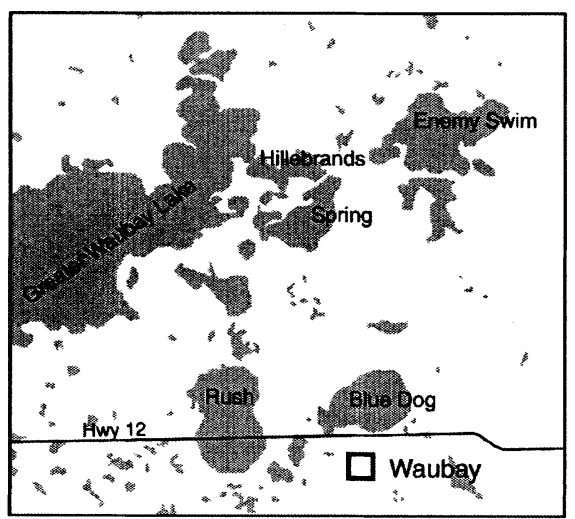

August 1995

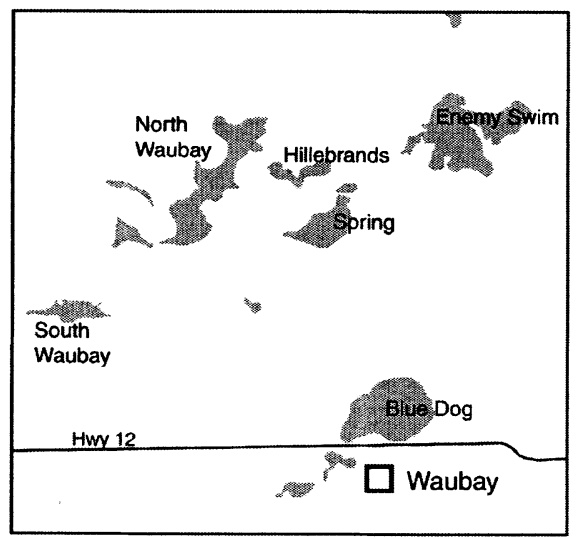

1939

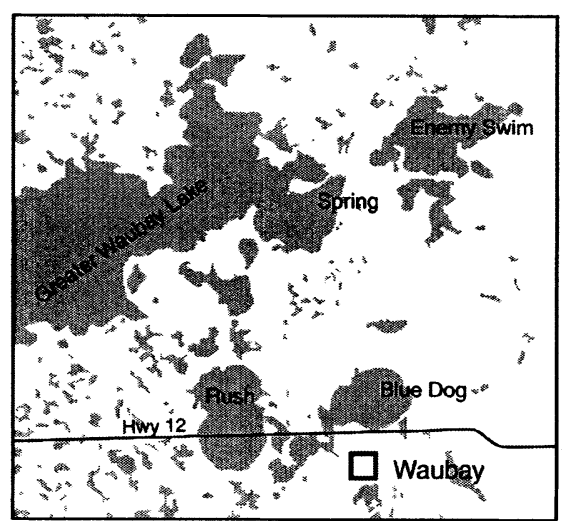

May 1997

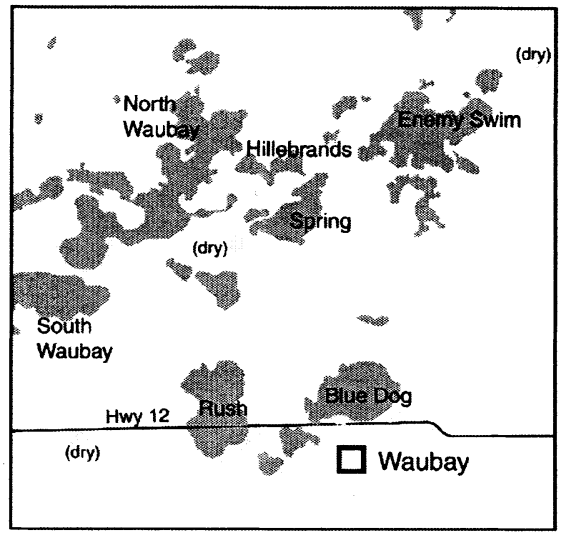

July 1976

Figure 2 Historical changes in lake and wetland extent in the Waubay Lake vicinity interpreted from Landsat imagery and aerial photography compiled by the US Geological Survey. 

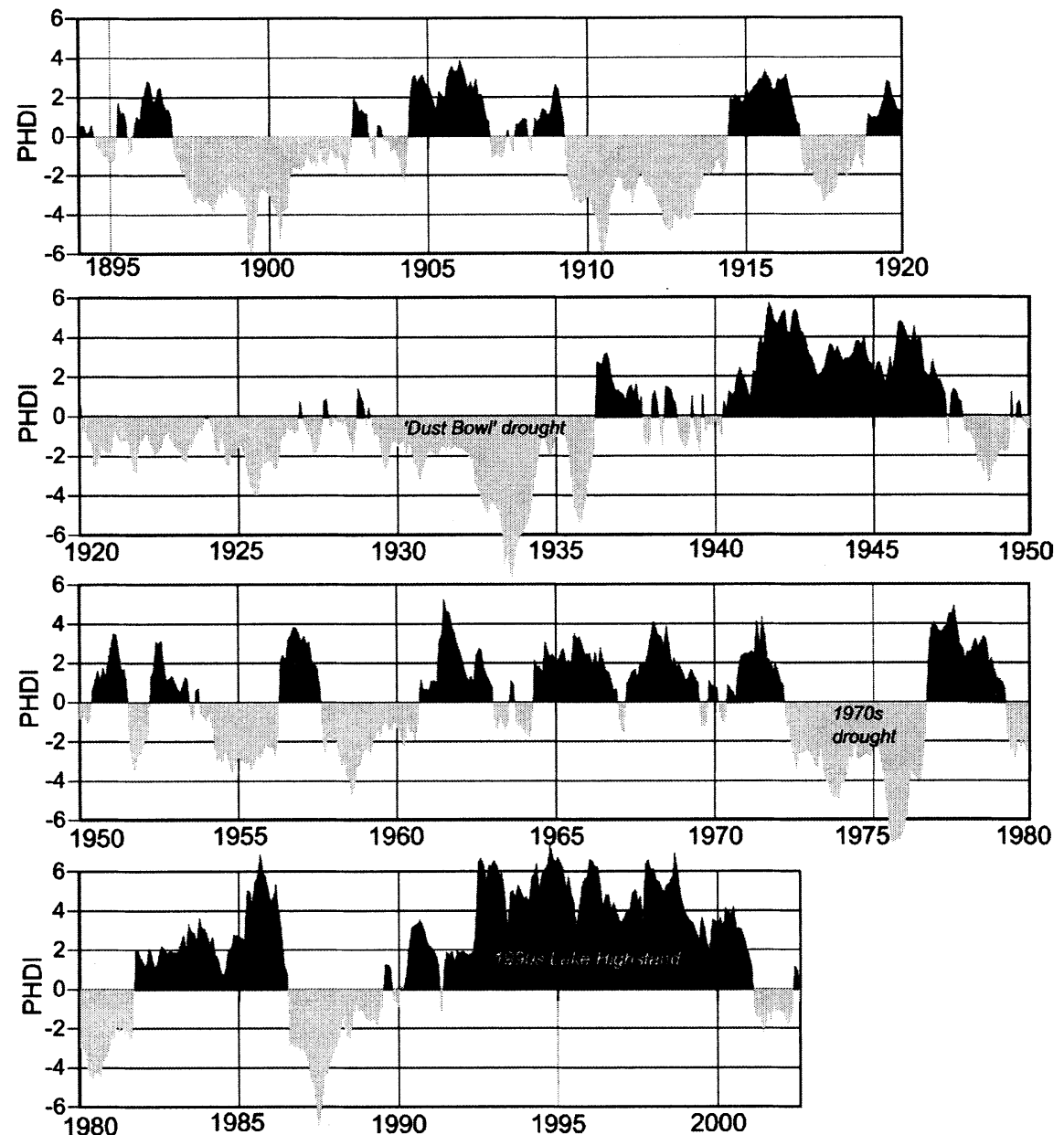

Figure 3 Time series of recent climate anomalies in northeastern South Dakota; tics mark end of calendar year. Values are the regionalized mean monthly Palmer Hydrologic Drought Index (PHDI) for South Dakota Division 3 (National Climatic Data Center archives at http://climvis.ncdc. noaa.gov/cgi-bin/ginterface). The PHDI is commonly employed as a metric of landscape moisture conditions in North America. The PHDI employs a rule-based water balance model, instrumental climate data and a simplified soil water storage routine to calculate normalized departures from average moisture conditions. The PHDI is very similar to the better-known Palmer Drought Severity Index (PDSI); PHDI weighting factors emphasize longer-term moisture departures than the PDSI when calculating index values. Negative values indicate drought, and positive values indicate wet conditions.

Smiley, 1996). Ring widths on cores were measured to the nearest $0.01 \mathrm{~mm}$ using a standard encoder/translator mechanism at the US Geological Survey's Midcontinent Ecological Science Center in Fort Collins, Colorado.

Ring series on individual cores were standardized using quotients between annual ring widths and overall means of ring widths. The effect of slower growth with age was removed using detrending curves. Ring-width series were detrended using best-fit straight lines constrained to horizontal or negative slopes or to negative exponential curves. The outermost rings of the Fort cores could not be dated precisely, but could be linked to the modern series by matching overall growth patterns using skeleton plots (which display ring-width patterns among cores) and correlation between ring measurements. The modern and Fort cores were from the same tree species (Q. macrocarpa) growing near each other in the same physiographic and climate region.

\section{Shoreline geomorphology}

Aerial photography and 7.5-minute topographic maps (1970 through 1973 base data) were examined to identify palaeoshorelines and spillway elevations of the Waubay complex, establish likely flow paths out of the Bitter Lake basin, and provide geomorphic evidence of lake discharge. Aerial photography of July, August and September 1939 (scale 1:20 000), was used to determine the likelihood of past streamflow along possible spillage routes. In the 1939 imagery, lake levels were near historic lows, and agriculture and other land uses caused less interference for identification of ancient shorelines than in more recent photography. Field visits for ground-truthing of features identified from maps and aerial photos were made in September 1999. Emphasis was given to spill paths between lakes, the positions and persistence of shorelines, and geomorphic characteristics along those paths identified as potential natural spillways from the Bitter Lake basin to the Big Sioux River.

\section{Lake-sediment records}

Core collection and processing

A $4 \mathrm{~m}$ long sediment core was collected with a modified Livingstone piston corer from the apparent deep point of the Spring Lake subbasin on 14 June 1999 (Figure 1). A $1.5 \mathrm{~m}$ long surface core preserving the sediment-water interface was collected at the same location. Livingstone-core sections were collected in $1 \mathrm{~m}$ overlapping drives, extruded, and transported to the 
University of Minnesota, Limnological Research Center (LRC). The surface core was extruded vertically and sectioned into $2 \mathrm{~cm}$ increments on site and stored in polypropylene jars for transport to the St Croix Watershed Research Station.

A single water sample for analysis of major-ion chemistry was collected from the well-mixed near-surface waters at the coring site. We assembled additional existing chemical data from Spring Lake, Waubay Lake and surrounding water bodies.

\section{Geochemical stratigraphy}

Dry-density, water content, organic content and carbonate content of the surface core and the first two sections of the $4 \mathrm{~m}$ core were determined by standard loss-on-ignition (LOI) techniques (Dean, 1974). LOI stratigraphies were used to crosscorrelate core sections and correct small field measurement errors.

Sediment mineralogy was measured by $\mathrm{X}$-ray diffraction (XRD) every $6 \mathrm{~cm}$. Ground subsamples of bulk sediment were scanned over $5^{\circ}$ to $65^{\circ}$ in $2 \theta$ on a Siemens D500 diffractometer. The Reference Intensity Ration (RIR) method was indexed to naturally occurring quartz to generate semi-quantitative estimates of mineral proportions, normalized to a three-phase system (aragonite + calcite + quartz).

\section{Lead-210 dating}

Twenty-three depth intervals from the surface core were analysed for ${ }^{210} \mathrm{~Pb}$ activity to determine age and recent sediment accumulation rates. Lead-210 was measured by high-temperature distillation and alpha spectrometry of its granddaughter product ${ }^{210} \mathrm{Po}$ (Eakins and Morrison, 1978). Unsupported ${ }^{210} \mathrm{~Pb}$ was calculated by subtracting supported activity from the total activity measured at each level; supported ${ }^{210} \mathrm{~Pb}$ was estimated from the mean of the lowermost two samples in the core. Dates and sedimentation rates were determined according to the c.r.s. (constant rate of supply) model (Appleby and Oldfield, 1978) with confidence intervals calculated by first-order error analysis of counting uncertainty (Binford, 1990).

\section{AMS ${ }^{14} C$ dating}

Two intervals were selected for accelerator mass spectrometry (AMS) ${ }^{14} \mathrm{C}$ dating based upon extrapolation of the ${ }^{210} \mathrm{~Pb}$ dating curve for the surface core. Sediment from the selected intervals was sieved at 250 and 125 microns, and the wet sieve residue was immersed in distilled water for microscopic selection of ${ }^{14} \mathrm{C}$ datable material. AMS samples were assembled from fine charcoal believed to be of airfall origin. Any abraded, rounded or discoloured material was rejected. After pretreatment $(\mathrm{HCl}$ and $\mathrm{NaOH})$ and reduction to graphite targets by the LRC AMS Target Preparation Lab, measurement of ${ }^{14} \mathrm{C}$ was conducted by the NSF-Arizona Accelerator Mass Spectrometry Laboratory. Radiocarbon dates were converted to calendar years AD using the CALIB 4.2 program of Stuiver and Reimer (1993) and calibration data sets from Stuiver et al. (1998).

\section{Pollen analysis}

Pollen analysis was conducted on selected intervals to identify the horizon representing onset of European settlement in the Waubay region, and specifically the arrival of Russian thistle (Salsola iberica) in 1885-90, which is known precisely for the Dakota region (Jacobson and Engstrom, 1989). Pollen samples were prepared according to procedures described by Faegri and Iversen (1975). Residues were mounted in silicon oil, and pollen identified under magnifications of $\times 400$ and $\times 1000$. At least 300 terrestrial pollen grains were counted in each sample.

\section{Ostracode abundance and elemental analysis}

Subsamples of each $2 \mathrm{~cm}$ core interval were sieved through 250 $\mu \mathrm{m}$ and $125 \mu \mathrm{m}$ screens using a manual sprayer and warm tap water. Ostracode shells and other residue were rinsed in distilled water, collected onto cellulose filters and air-dried. The dried sieve residues were examined for ostracode shells and ranked for abundances of the five most common ostracode species; identifications were confirmed by Rick Forester (USGS, Denver). Forty juvenile shells (A-1 and A-2 instars) of Candona rawsoni were selected from each core interval for chemical analysis. Broken, visibly etched and taxonomically uncertain shells were excluded from the sample sets.

Shells were cleaned for 5-7 hours in a solution of $50 \%$ commercial bleach followed by a sequence of six immersion rinses in high purity deionized water. Shells (seven shells per depth increment) selected for elemental analysis were given a final rinse in deionized water followed by reagent grade absolute alcohol. The cleaned shells were then dissolved in acid-washed glass vials by reaction with high-purity anhydrous $\mathrm{H}_{3} \mathrm{PO}_{4}$. Following dilution with a Rh-spiked standard solution, elemental analysis $(\mathrm{Ca}, \mathrm{Mg}, \mathrm{Sr}$ and $\mathrm{Ba})$ of the dissolved shells was performed by inductively coupled plasma mass spectrometry (ICP-MS) in the Department of Geology and Geophysics Geochemistry Lab (University of Minnesota). Standard QA/QC procedures included standard and blank analyses every fourth sample and five replicate measurements per sample element.

\section{Results and discussion}

\section{Tree-ring chronology}

Sampled trees ranged in age from 54 to 161 years. The oldest trees found were bur oak, with the largest number of old oak trees found on West Woods Island in Waubay Lake, including the oldest core in the sample (161 years; first ring in 1839). Seventeen of the oldest cores were used to construct the chronology. Eight cores in the total sample had their first growth ring in or prior to 1864 , the year Fort Sisseton was built, with 13 years of overlap between Fort and living tree series. With this overlap, the Fort Sisseton series dates to 1851 . The complete chronology (Figure 4) covers the years $1674-1998$, a total of 325 years.

\section{Ring-width and precipitation records}

The ring-width patterns of the chronology correlate well with precipitation records and closely match known wet and dry periods. The correlation coefficient between ring-index values in the chronology and annual precipitation at Webster, South Dakota, is positive and statistically significant $(r=0.49$; $\mathrm{p}<0.0001$ ). The severe drought of the $1930 \mathrm{~s}$ is clearly evident in the chronology as the twentieth-century minimum in growth rates (Figure 4). The low rainfall years in the 1970s appear as a less extreme trough in growth. Single years in the chronology also match up with known precipitation extremes. For example, a very low ring-index value for 1976 coincides with the driest year of the twentieth century, with $19.6 \mathrm{~cm}$ of precipitation at Webster, SD. The next year (1977) was very wet $(76.2 \mathrm{~cm})$ and initiated a two-year response of increasing ring width. In 1978, ring index was near the maximum for this century (Figure 4). Moreover, the series of years with consistently wide growth rings in the mid-1990s corresponds to some of the wettest years in the climate record. Overall, the ringwidth patterns consistently reflect the known precipitation 

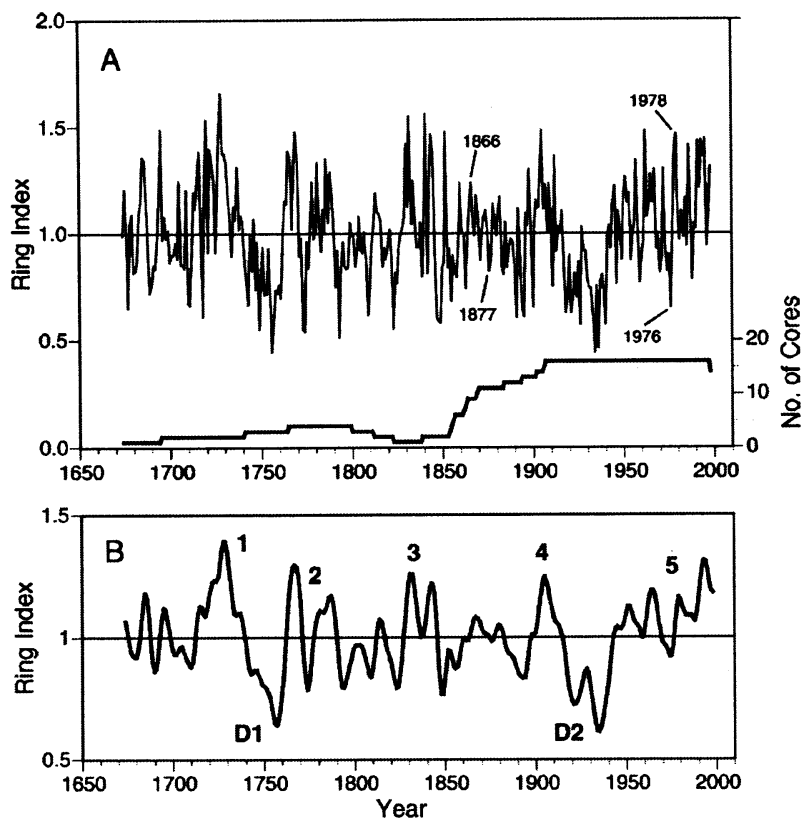

Figure 4 (A) Time series of detrended Waubay Lake Quercus macrocarpa ring index and sample size. (B) Ten-year spline fit to the $Q$. macrocarpa time series, highlighting extended wet $(1-5)$ and dry periods (D1, D2) in the record.

patterns in this century, supporting use of the chronology to identify earlier wet and dry periods.

The portion of the chronology using only Fort cores, however, needs to be interpreted with caution because of the small sample size and short overlap with the modern cores. Nonetheless, government surveys and historical records from the $1860 \mathrm{~s}$ and $1870 \mathrm{~s}$ show initially high but declining water levels (Table 1; Bennett, 1878), a trend that matches declining bur oak growth rates in our chronology.

Finally, the Waubay tree-ring record correlates well $(\mathrm{r}=0.55)$ with tree-ring chronologies from Lake Herman $(160 \mathrm{~km}$ south of Waubay; Sieg and Meko, 1995) and $(\mathrm{r}=0.58)$ with annual July Palmer drought severity indices (PDSI) derived from tree rings in other locales and extrapolated to northeastern SD by Cooke et al. (1996).

\section{Wet/dry periods}

The smoothed ring-index time series indicates the occurrence of five wet periods over the 325 -year period (Figure 4). The wet peaks are nearly evenly spaced, averaging 65 years in recurrence. Based on analogy to present-day pluvial conditions, we believe that each of the peaks was wet enough to have produced lake levels well above average. Peaks 1 and 5 are distinguished by wide breadth ( $40-50$ years), broken by occasional dry years but not reversed by intervals of dry years. Maximum growth rates are higher in peak 1, but peak 5 has longer duration.

Only peak 1 resembles the duration and intensity of peak 5 (known to have produced extreme lake flooding). We thus infer that sustained wet climate anomalies like that producing the 1990s highstand occurred twice in the 325-year tree-ring record. Two strong drought periods are also evident in the chronology. The years with lowest growth rates in the chronology correspond to the 1930 s drought period. A similar period of low growth rates occurred between 1740 and 1760 (Figure 4). The drought indicated in the mid-1700s may have been longer (more consecutive years of below-average moisture) but less intense (fewer extreme values) than the 1930s drought. Thus, the observed frequency of drought severity similar to the 1930s is two events in 325 years, the same as that seen for extreme wet periods.

\section{Shorelines and channelways}

Historical and recent records, geomorphic considerations and modelling results (Niehus et al., 1999a; 1999b) indicate that most lakes of the Waubay chain except Bitter Lake periodically have had water levels high enough to cause overflow. Beginning in the late 1990s, rising water levels of Rush Lake resulted in limited flows spilling into Bitter Lake.

Recent overflow from the two upper-watershed lakes, Enemy Swim and Pickerel, has produced gravel beds and well-defined channel morphologies. These features are less apparent along spill paths between the lower lakes, which prior to infrastructure development were separated by marshy lowlands. The channelway from Little Rush Lake to Bitter Lake has the appearance of being occupied by flowing water only recently; well-defined channel features are lacking.

From aerial photography of 1939 and field observations, it is apparent that the lower lakes have exhibited varying water levels resulting in the formation of numerous beachlines. A point of land extending as a peninsula or island into the middle of Waubay Lake (Figure 1), exhibits well-defined shoreline features as high as $549.6 \mathrm{~m}$ elevation; shorelines were not recognized at higher elevations of the island, which has an estimated maximum elevation of $552.9 \mathrm{~m}$. Prior to development, lake elevations of $549.6 \mathrm{~m}$ overtopped divides separating Blue Dog, Waubay, Rush, Little Rush and Bitter Lakes. Inspection of aerial photography and supporting field evidence show no shorelines higher than an elevation of about $549.6 \mathrm{~m}$ preserved anywhere in the Bitter/Waubay basin complex.

Two flow paths, the most likely routes for spillage from the Bitter Lake basin to the Big Sioux River, have modern divides at $552.02 \mathrm{~m}$ and $552.33 \mathrm{~m}$ (Figure 1). Examination of these channelways shows that the hummocky sideslopes and gently undulating bottomland are dominated by glacial till and sandy outwash presumably deposited at the time of glacial retreat. No lacustrine sediment attributable to levels of Bitter Lake between 549.6 and $552 \mathrm{~m}$ was recognized. Irregular sideslopes of the channelways maintain a relict morphology of glacial-till geology and exhibit no evidence of modification by flowing water. Small lakes and marshes occupy the channelways, which are interpreted to be remnant watercourses that conveyed meltwater during deglaciation; no landforms along the channelways have the appearance or sediment characteristics of either modern or ancient flood plains. Thus, field examination of the two channelways indicates that significant spillage from Bitter Lake has not occurred since deposition of glacial till and outwash in lateglacial times. Additional support for this interpretation can be seen in a ${ }^{14} \mathrm{C}$ age of $8090 \pm 40$ radiocarbon years BP, measured on bulk organic material in sands collected from $2.4 \mathrm{~m}$ subsurface at the potential spill point of the Bitter Lake basin. Frequent or persistent spill from Bitter Lake would, we believe, have removed this evidence of earlyHolocene deposition at this site.

Owing to a larger basin area for Bitter Lake than the other lakes of the Waubay complex, a substantial volume of water must flow from Rush Lake into the Bitter Lake basin before spillage of Bitter Lake is possible. This extensive surface area implies that substantial water is lost by evaporation and perhaps infiltration to the groundwater system before spillage can occur. The highest recognized beach deposits $(549.6 \mathrm{~m})$ are only slightly higher than the natural spillway between Rush and Bitter Lakes $(548.3 \mathrm{~m})$. Thus overflow from Waubay and subsequent evaporation in the Bitter Lake basin has served to 
control hydrologic balance and maximum lake elevation in the Waubay complex, evidently without significant surface outflow to the Big Sioux River. That preserved shorelines at approximately $549 \mathrm{~m}$ also occur around Bitter Lake indicates that on at least one occasion climatic conditions were sufficiently wet to fill the Bitter basin and form one large lake with a shoreline of common elevation. Whether this lake level was attained more than once cannot presently be determined.

\section{Lake sediments}

\section{Lithology and mineralogy}

LOI results show the Spring Lake core consists of 10-30\% organic matter, $25-35 \%$ carbonate minerals and $40-55 \%$ other inorganic matter (primarily detrital silicates). The organic content increases irregularly upcore, beginning well before the onset of European settlement $(64 \mathrm{~cm})$ (Figure 5). Small-scale variations are reproduced faithfully in the overlaps between core sections, allowing for precise adjustment of fieldmeasured core depth between Livingstone drives 1 and 2 . Adjusted core stratigraphies show almost perfect alignment of LOI profiles (Figure 5). Ostracode analyses were performed on the upper $200 \mathrm{~cm}$ of sediment: $0-138 \mathrm{~cm}$ (adjusted depths) of the surface core and $6-70 \mathrm{~cm}(136-200 \mathrm{~cm}$ adjusted depths) of Livingstone drive 2.

A semi-quantitative XRD plot of sediment mineralogy (Figure 5) shows an upcore increase in aragonite (necessarily endogenic), while quartz (presumed to be detrital) displays a corresponding decline. The two minerals show an antiphase relationship indicative of variable detrital dilution of the endogenic carbonate. The calcite component displays a more complex relation to the other two phases, in keeping with multiple origins of sedimentary calcite (endogenic, biogenic and detrital). The predominance of aragonite throughout the

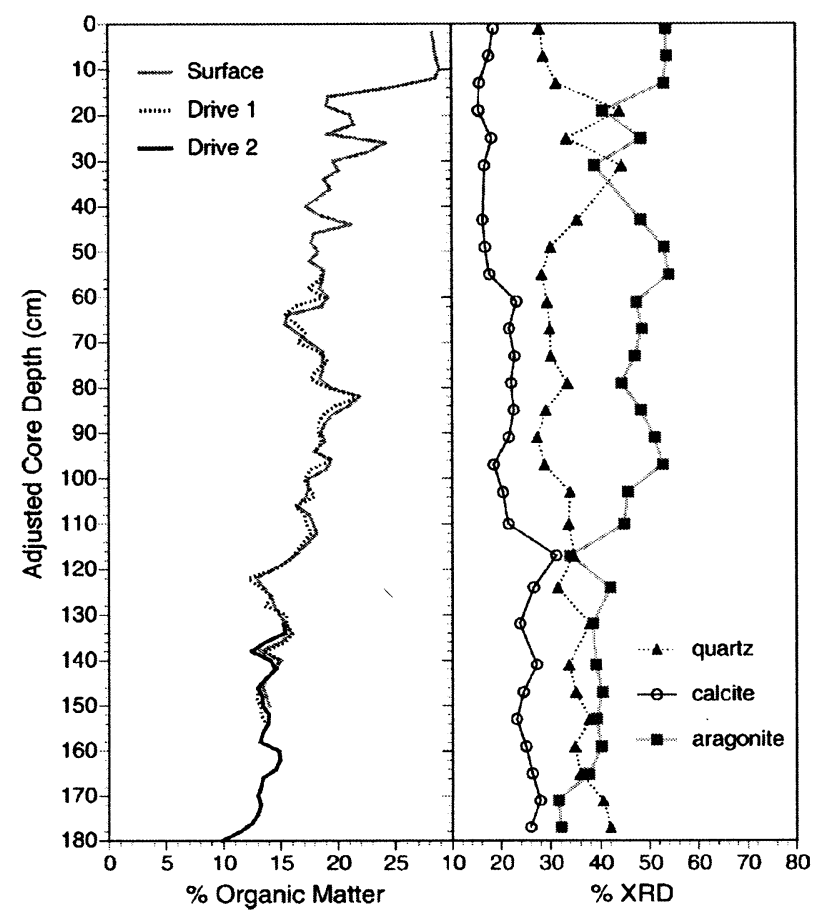

Figure 5 Loss-on-ignition and XRD mineralogy for the Spring Lake sediment core. Profiles of \% organic matter show correlation of the surface core with the $4 \mathrm{~m}$ Livingstone core. Field depths were adjusted for coring errors $(\leq 4 \mathrm{~cm})$ to match stratigraphic detail at the overlap between core sections. record indicates maintenance of relatively high lakewater $\mathrm{Mg}^{2+} / \mathrm{Ca}^{2+}$, even during periods of lake highstand and low salinities (Müller et al., 1972)

\section{Core chronology}

The profile of total ${ }^{210} \mathrm{~Pb}$ activity shows a monotonic decline from $12.2 \mathrm{pCi} / \mathrm{g}$ at the surface to a near-constant $0.83 \mathrm{pCi} / \mathrm{g}$ below $78 \mathrm{~cm}$ core depth (Figure 6A). Applying the constant rate of supply (c.r.s.) model to these data yields a basal date of $1849 \pm 22$ years at $78 \mathrm{~cm}$ (Figure 6B) and sedimentation rates varying from 0.06 to $0.12 \mathrm{~g} \mathrm{~cm}^{-2} \mathrm{yr}^{-1}$ (Figure $6 \mathrm{C}$ ). Dating uncertainty increases substantially for strata older than about 1900 , as total ${ }^{210} \mathrm{~Pb}$ activity approaches supported values $(0.83 \mathrm{pCi} / \mathrm{g})$.

The chronology of pre- 1850 sediments is provided by linear interpolation between the two AMS ${ }^{14} \mathrm{C}$ dates and the basal ${ }^{210} \mathrm{~Pb}$ date at $78 \mathrm{~cm}(1849)$. The ${ }^{14} \mathrm{C}$ date at $148-150 \mathrm{~cm}$ (adjusted depth) is $710 \pm 40 \mathrm{yr}$ BP (AA37099), while that at $226-228 \mathrm{~cm}$ is $1250 \pm 40 \mathrm{yr}$ BP (AA37098). Calibration of these ${ }^{14} \mathrm{C}$ dates yields calendrical dates of $\mathrm{AD} 775$ (AD 685-877, \pm 2 sigma) and AD 1287 (AD 1235-1390, \pm 2 sigma), respectively. A plot of calibrated date versus depth (Figure 6D) indicates a near-constant sediment accumulation rate of $0.14 \mathrm{~cm} \mathrm{yr}^{-1}$. This rate is substantially slower than the average accumulation rate for the ${ }^{210} \mathrm{~Pb}$ dated section of $0.51 \mathrm{~cm} \mathrm{yr}^{-1}$. The apparent acceleration of recent sedimentation reflects both the upward increase in sediment porosity and an acceleration of sediment flux to the lake caused by post-European land-use changes. Results from pollen analysis provide strong independent support for the ${ }^{210} \mathrm{~Pb}$ chronology. Abrupt changes in pollen percentages beginning at $64 \mathrm{~cm}$ core depth - in particular the decline in oak (Quercus) and other riparian forest types (elm, ash, birch) and the corresponding rise in grasses (Poaceae) and weedy taxa (Ambrosia, chenopods) - indicate the late-1800s spread of European agriculture into the Waubay region (Figure 7). The most precise pollen marker is provided by Russian thistle (Salsola), an aggressive Eurasian weed that arrived in Day County around 1885 (Jacobson and Engstrom, 1989). Its appearance in the Spring Lake core at $64 \mathrm{~cm}$ corresponds to a virtually indistinguishable ${ }^{210} \mathrm{~Pb}$ date of $1886 \pm 7.5$ years (Figure 6B).

\section{Ostracode abundance}

Figure 8 shows the abundance of the five dominant ostracode taxa identified in the Spring Lake core. Candona rawsoni, a widespread species of the NGP having broad ecological tolerance, is the most common fossil taxa in most intervals and is ubiquitous in the core. Between AD 1000 and 1500, Candona ohioensis comprises an important component of the fossil ostracode fauna, with three distinct peaks in abundance centred approximately on the years AD 1150, 1250 and 1400 . At the peak of these cycles, $C$. ohioensis shell abundance approaches or exceeds that of C. rawsoni. From AD 1500 to the present, $C$. ohioensis appears rarely and in low abundance. Limnocythere itasca occurs at low to moderate numbers throughout most of the record. Between AD 1000 and 1500, its abundance peaks coincident with that of $C$. ohioensis. After AD 1500, when $C$. ohioensis essentially disappears from the fossil record, $L$. itasca displays another broad peak centred on $c$. AD 1700, coincident with a peak in $C$. rawsoni numbers and in total ostracode shells. From AD 1800 to the present, L. itasca occurs frequently but in low numbers. Potamocypris unicaudata is apparently absent from the record from $\mathrm{AD}$ 1000 to approximately 1900 , after which it occurs at low abundances. Heterocypris glaucus occurs sporadically and at low numbers prior to the late nineteenth century. 

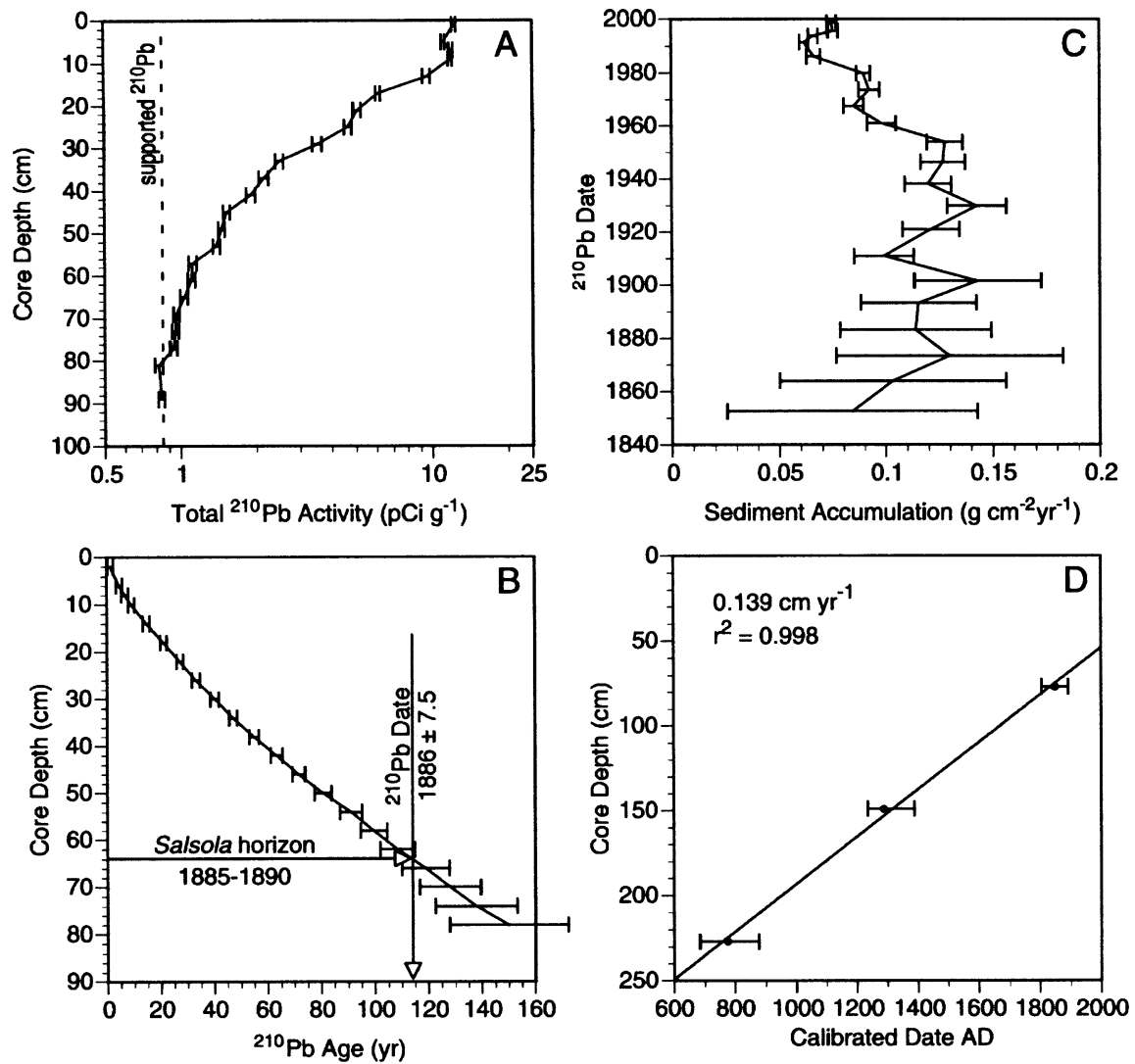

Figure 6 Chronology and sedimentation rate for the Spring Lake sediment core. (A) Lead-210 activity profile from short core samples. (B) Age/depth profile determined according to the constant rate of supply (c.r.s.) model; error bars represent \pm 1 standard deviation. The date at which Russian thistle (Salsola iberica) first appears in the pollen record corresponds to a ${ }^{210} \mathrm{~Pb}$ date of 1886 ; Russian thistle spread throughout Day County between 1885 and 1890 . (C) Sediment mass accumulation rate over ${ }^{210} \mathrm{~Pb}$ dated interval. (D) Age/depth model for ${ }^{14} \mathrm{C}$ dates calibrated to the calendrical timescale; error bars represent \pm 1 s.d.

\section{Elemental shell chemistry}

Molar ratios of $\mathrm{Mg}$ and $\mathrm{Sr}$ to $\mathrm{Ca}$ in the calcite shells of C. rawsoni are shown stratigraphically in Figure 9. From $\mathrm{AD}$ 1000 to 1500 , ostracode $\mathrm{Mg} / \mathrm{Ca}$ expresses a sequence of welldefined fluctuations with a period of 150 to 200 years. The three low- $\mathrm{Mg} / \mathrm{Ca}$ intervals, centred on $\mathrm{AD} 1050,1250$ and 1400 correspond with periods of increased abundance of $L$. itasca and $C$. ohioensis shells in the Spring Lake core (Figure 8). Between $c$. AD 1500 and 1800 , the period of $\mathrm{Mg} / \mathrm{Ca}$ fluctuation appears to decrease to approximately 100 years, and from $c .1800$ to the present the $\mathrm{Mg} / \mathrm{Ca}$ record shows even shorter-period variation. Historically recorded droughts of the 1890s and 1930s are expressed as maxima in ostracodeshell $\mathrm{Mg} / \mathrm{Ca}$ during those periods, while wet periods during

\section{Spring Lake, South Dakota, pollen percentages analyst: B.C.S. Hansen}
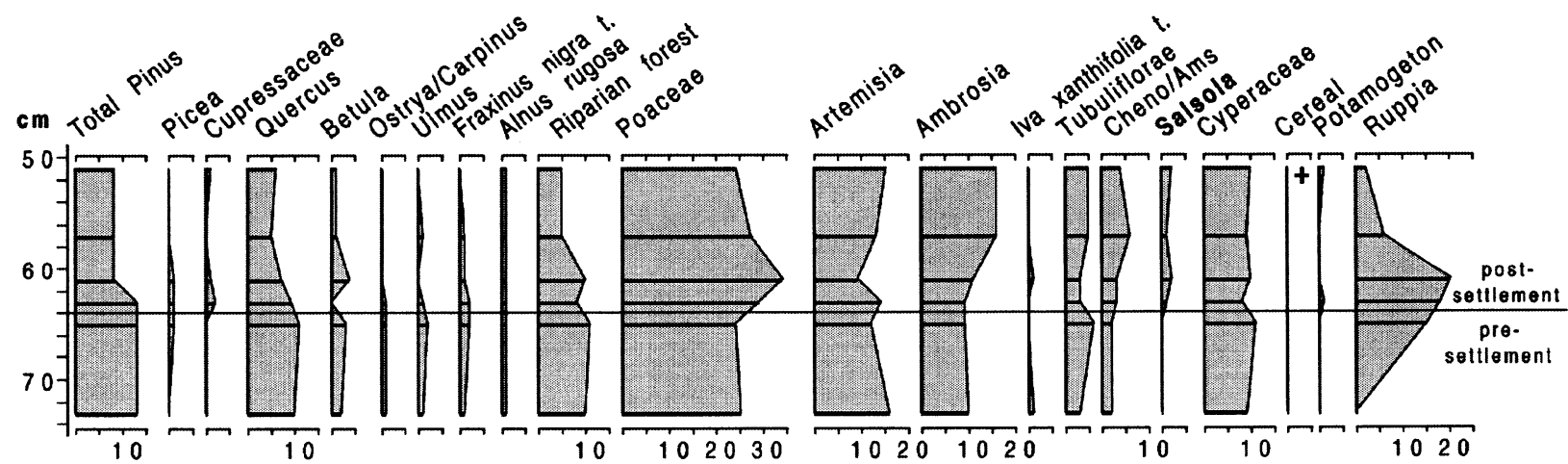

Figure 7 Pollen percentage diagrams from the Spring Lake surface core showing changes in major pollen types that correspond to the arrival of European agriculture in the Waubay region. 


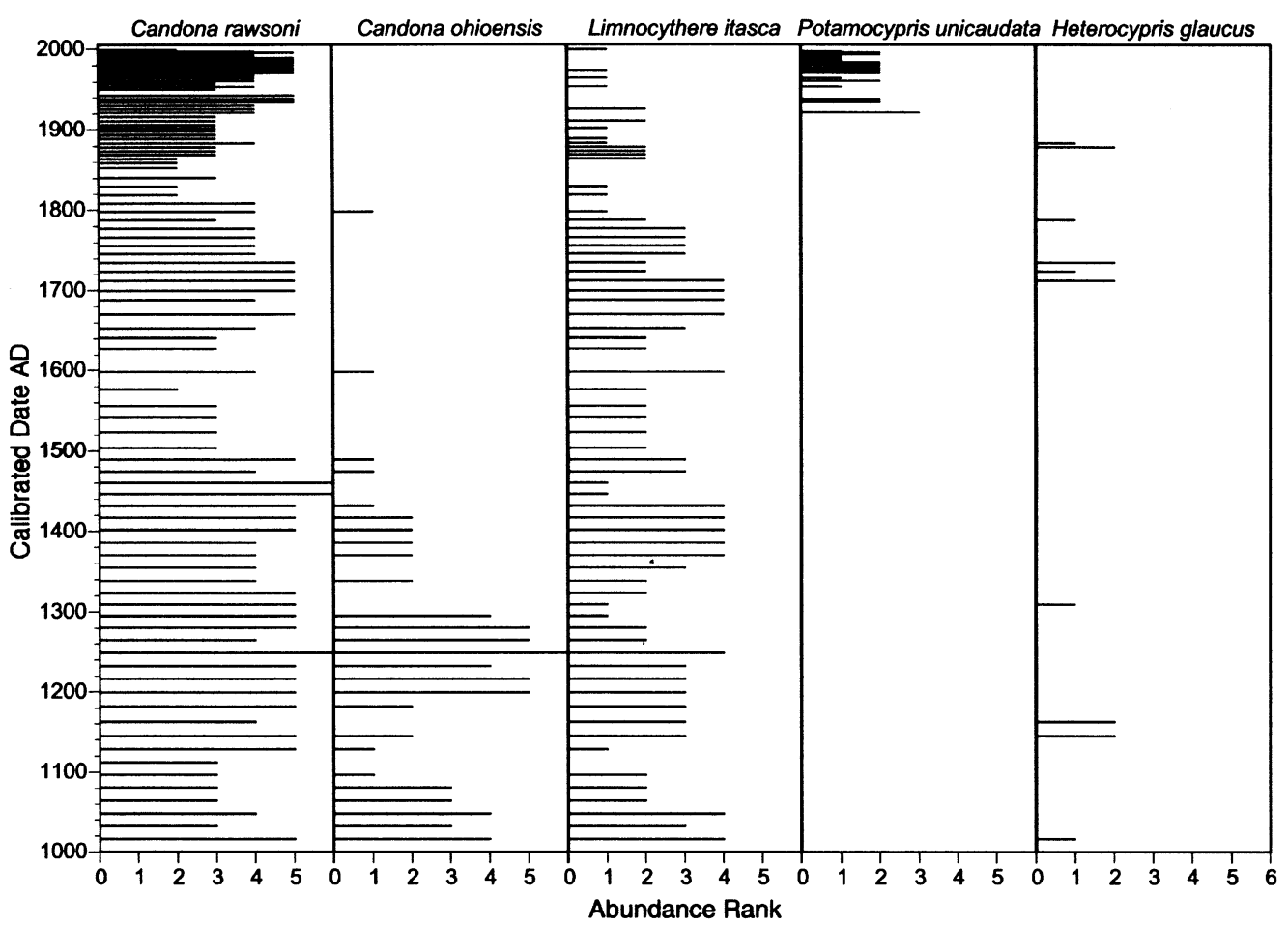

Figure 8 Abundance profiles for the five major ostracode species found in the Spring Lake core. Relative abundance increases with ranking; abundance rank $0=$ absent.

the early twentieth century and in the 1960 s are reflected as minima in the $\mathrm{Mg} / \mathrm{Ca}$ curve. Contrary to a straightforward model of lake dilution, however, the youngest intervals of the core (interpreted by ${ }^{210} \mathrm{~Pb}$ as dating from the current highstand) do not show declining $\mathrm{Mg} / \mathrm{Ca}$ values.
Ratios of $\mathrm{Sr} / \mathrm{Ca}$, plotted on an inverted scale (Figure 9), display a negatively covariant relationship to $\mathrm{Mg} / \mathrm{Ca}$ over most of the record. All of the $100-150$-year $\mathrm{Mg} / \mathrm{Ca}$ events from $\mathrm{AD} 1000$ to 1800 show corresponding inverse $\mathrm{Sr} / \mathrm{Ca}$ trends. From AD 1800 to the present, the inverse relationship

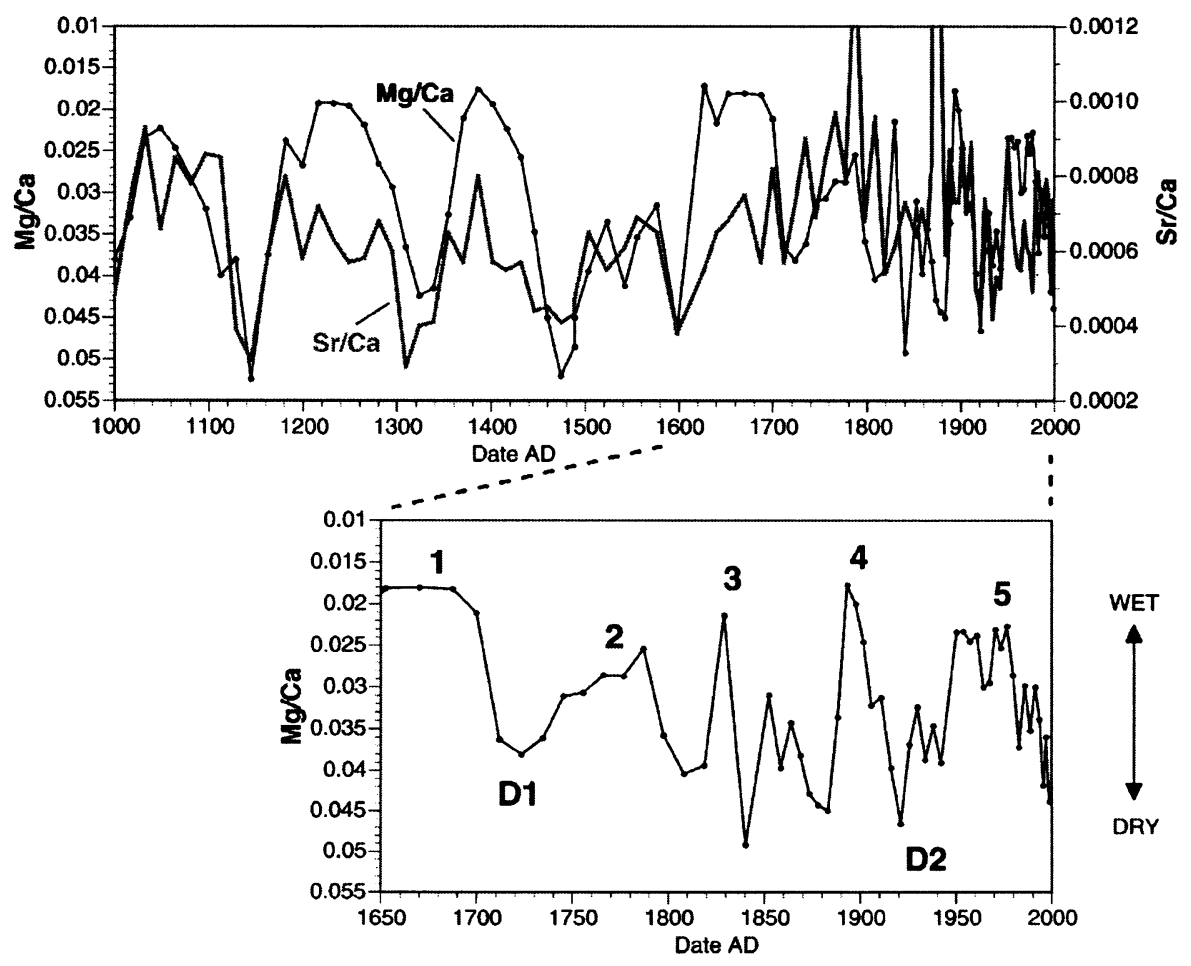

Figure 9 Stratigraphic changes in elemental composition of Candona rawsoni shells in the Spring Lake core. The scale for ostracode $\mathrm{Mg} / \mathrm{Ca}$ is inverted so that freshening events (wet intervals) are represented by upward excursions in both $\mathrm{Mg} / \mathrm{Ca}$ and $\mathrm{Sr} / \mathrm{Ca}$ curves. $\mathrm{Major}$ wet periods $(1-5)$ and drought intervals (D1, D2) identified from local tree-ring data are compared with $\mathrm{Mg} / \mathrm{Ca}$ events on the expanded timescale. 
is occasionally interrupted by episodes of coherent increase in $\mathrm{Mg} / \mathrm{Ca}$ and $\mathrm{Sr} / \mathrm{Ca}$, notably during the wet period of the late nineteenth century.

Water chemistry

The Spring Lake water sample of June 1999 had a salinity of $1.65 \%$ and was dominated by $\mathrm{Mg}^{2+}, \mathrm{Na}^{+}$and $\mathrm{SO}_{4}{ }^{2-}$ ions, similar to other regional lakes. Molar ratios for $\mathrm{Mg}^{2+} / \mathrm{Ca}^{2+}$ and $\mathrm{Sr}^{2+} / \mathrm{Ca}^{2+}$ were 4.52 and $1.9 \times 10^{-3}$, respectively (Table 2). We found only limited additional data from prior years for the Waubay lake system. Measurements of specific conductance by the US Geological Survey (USGS) in 1995 show that Spring Lake was dilute relative to Waubay Lake early in the present lake highstand, prior to the coalescence of Waubay and Spring Lakes (Table 3). In 1995, the Spring Lake specific conductance of $1040 \mu \mathrm{S} \mathrm{cm}{ }^{-1}$ was lower than that for Waubay $\left(2490 \mu \mathrm{S} \mathrm{cm}^{-1}\right)$ and lower than the $2050 \mu \mathrm{S}$ $\mathrm{cm}^{-1}$ we measured in 1999 , following lake coalescence. Archival data for Waubay Lake show specific conductance values ranging between approximately 4000 and $11000 \mu \mathrm{S}$ $\mathrm{cm}^{-1}$ since 1971. Anecdotal information from the 1930s drought indicates that Spring Lake remained flooded and relatively fresh, suggesting the importance of groundwater through-flow during arid periods (Rothrock, 1935).

\section{Salinity and hydrologic reconstruction}

Spring Lake ostracodes provide an internally coherent, highresolution record of hydrochemical changes in the Waubay Lake system. The $\mathrm{Mg} / \mathrm{Ca}$ content of ostracode shells is a well-established method for reconstructing salinity changes in evaporative lakes, based on both empirical and experimental evidence (Chivas et al., 1986; Engstrom and Nelson, 1991; Holmes, 1996; De Deckker et al., 1999). In semi-arid regions such as the NGP, changes in moisture balance directly influence lake salinities through concentration or dilution of dissolved salts. Because $\mathrm{Ca}^{2+}$ is controlled by carbonate precipitation in moderately saline waters and $\mathrm{Mg}^{2+}$ behaves relatively conservatively, lakewater $\mathrm{Mg}^{2+} / \mathrm{Ca}^{2+}$ closely tracks salinity, and by extension tracks hydrologic and climatic

Table 2 Ionic chemistry of Spring Lake, June 1999

\begin{tabular}{llc}
\hline Ion & ppm & meq/L \\
\hline $\mathrm{Na}^{+}$ & 100 & 4.36 \\
$\mathrm{~K}^{+}$ & 46 & 1.19 \\
$\mathrm{Mg}^{2+}$ & 194 & 15.94 \\
$\mathrm{Ca}^{2+}$ & 71 & 3.52 \\
$\mathrm{Sr}^{2+}$ & 0.288 & 0.0066 \\
$\mathrm{Ba}^{2+}$ & 0.075 & 0.0011 \\
$\mathrm{CI}^{-}$ & 35 & 0.98 \\
$\mathrm{SO}_{4}{ }^{-}$ & 776 & 16.16 \\
$\mathrm{HCO}_{3}{ }^{-}$ & 424 & 6.96 \\
$\mathrm{Cations}^{+}$ & & 25.01 \\
Anions & & 24.09 \\
Salinity & $1.65 \% 0$ & \\
Conductivity & $2050 \mu \mathrm{cm}^{-1}$ & \\
\hline
\end{tabular}

Table 3 Specific conductance of Waubay system lakes, October 1995

\begin{tabular}{lc}
\hline Lake & $\mu \mathrm{S} \mathrm{cm}$ \\
\hline Hillebrands/Waubay & 2490 \\
Swan Pond & 2440 \\
Spring Lake & 1040 \\
Rush Lake & 461 \\
\hline
\end{tabular}

change. Ostracodes, in turn, incorporate $\mathrm{Mg}$ into their shells in direct proportion to the $\mathrm{Mg}^{2+} / \mathrm{Ca}^{2+}$ ratio of the surrounding water. Vital effects arising from the biotic nature of shell calcification complicate the picture of $\mathbf{M g}$ uptake and preclude a precise thermodynamic relationship between shell chemistry and lake salinity (Xia et al., 1997a; Wansard et al., 1998). Nonetheless, recent studies have demonstrated that ostracode $\mathrm{Mg} / \mathrm{Ca}$ ratios closely track other robust salinity proxies such as diatom-based salinity inference models (Fritz et al., 2000).

In Spring Lake both ostracode $\mathrm{Sr} / \mathrm{Ca}$ ratios and ostracode abundance data are coherent with the $\mathrm{Mg} / \mathrm{Ca}$ record and its palaeohydrologic interpretation. Ostracode $\mathrm{Sr} / \mathrm{Ca}$ is negatively covariant with ostracode $\mathrm{Mg} / \mathrm{Ca}$ in Spring Lake because of preferential uptake of $\mathrm{Sr}$ by precipitating aragonite, which lowers lakewater $\mathrm{Sr}^{2+} / \mathrm{Ca}^{2+}$ as salinity increases. An inverse correlation between ostracode $\mathrm{Mg} / \mathrm{Ca}$ and $\mathrm{Sr} / \mathrm{Ca}$ ratios occurs in other sediment records from Dakota lakes in which aragonite is the dominant endogenic carbonate (Fritz et al., 1994; Haskell et al., 1996; Xia et al., 1997b). High abundances of Limnocythere itasca (and, in some instances, Candona ohioensis), during low $\mathrm{Mg} / \mathrm{Ca}$ events centred on $\mathrm{AD}$ $1050,1250,1400$ and 1660 also support the interpretation of $\mathrm{Mg} / \mathrm{Ca}$ minima as freshening lake highstands. Both taxa prefer less saline conditions than does C. rawsoni (Smith, 1993).

\section{Regional comparisons}

The reliability of ostracode-shell chemistry in evaluating the frequency and severity of Spring Lake highstands hinges on (i) the coherence of the reconstruction with other regional records, and (ii) correlation with instrumental data and shorter-term proxy records from the immediate vicinity of Waubay Lake. Regional context is provided by the palaeohydrologic synthesis of Fritz et al. (2000), wherein highresolution late-Holocene salinity histories from diatoms and ostracodes are compared among three North Dakota sites (Rice, Moon and Coldwater Lakes; Figure 10). These records show considerable regional coherence in direction and duration of inferred climatic transients, with distinctions related to position along regional climatic gradients and hydraulic idiosyncrasies of the lakes.

The Spring Lake $\mathrm{Mg} / \mathrm{Ca}$ profile is remarkably similar to these records, especially those from Rice and Coldwater Lakes. Temporal correlation among individual lake records carries uncertainty; the standard error of AMS ${ }^{14} \mathrm{C}$ dates reported by Fritz et al. (2000) is 50 years, and the AMS dates controlling our Spring Lake chronology carry standard errors of 40 years. Similarities in duration and frequency of geochemically expressed hydrologic events between Spring Lake and these other NGP records are nevertheless clear, and we can propose correspondence between particular Spring Lake events and those elsewhere in the regional record with some confidence. Sustained freshwater episodes (highstands) centred on AD 1250,1400 and 1660 are particularly well expressed regionally, as are the sustained high-salinity events centred on AD 1330, 1480,1600 and 1740.

We observe less consistent coherence with a 600 -year treering precipitation reconstruction for southern Manitoba (St George and Nielsen, 2002). Spring Lake freshwater phases centred on AD 1400 and 1660 appear to correlate with highprecipitation periods in the Red River record. Spring Lake saline phases centred on AD 1480 and 1740 correspond with extended low-precipitation anomalies in the Manitoba reconstruction. Spring Lake exhibits unusually persistent highsalinity conditions throughout the sixteenth century AD. This feature contrasts with the southern Manitoba record (which shows a prominent wet anomaly in the late sixteenth and early seventeenth centuries $\mathrm{AD}$ ) but is consistent with the synthesis 


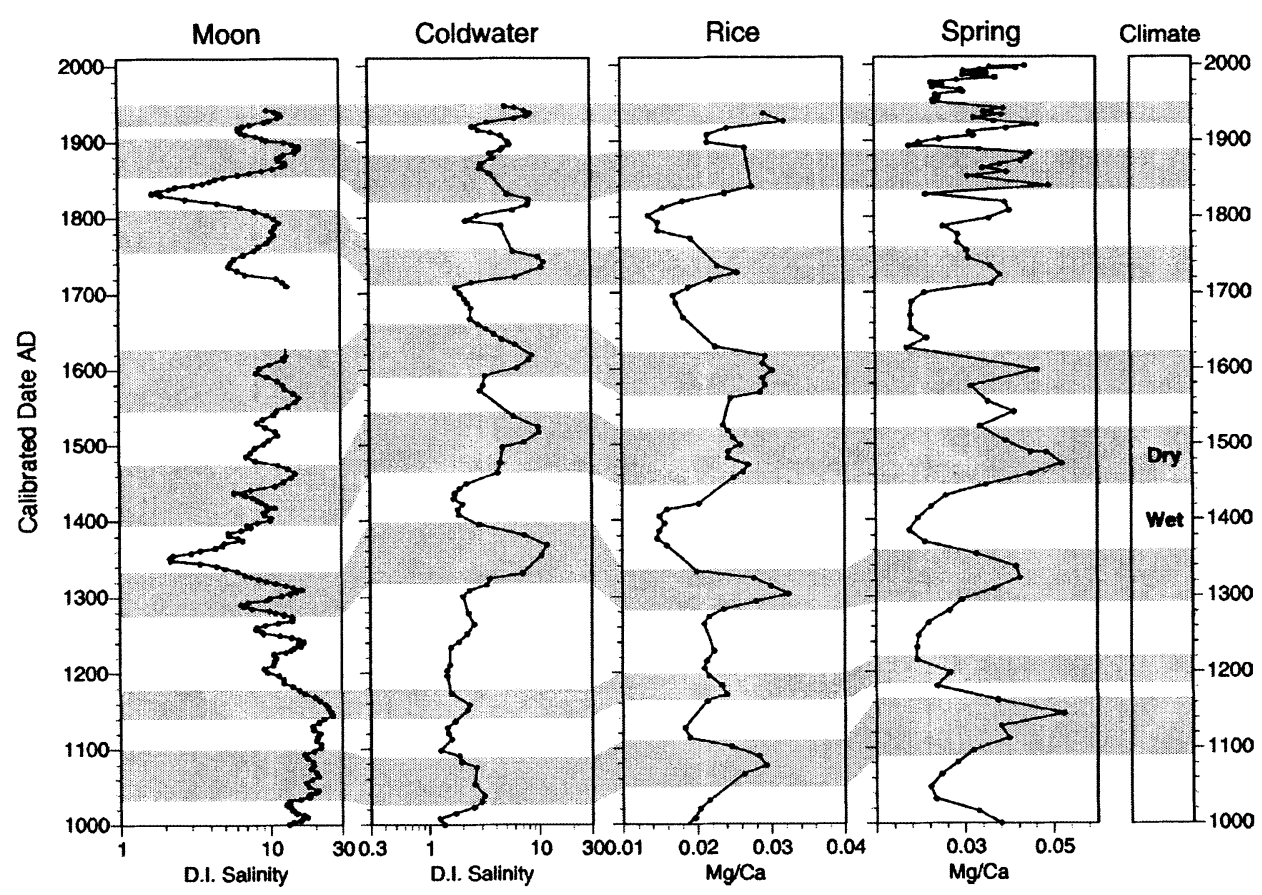

Figure 10 Comparison of the Candona rawsoni $\mathrm{Mg} / \mathrm{Ca}$ profile from Spring Lake with other high-resolution palaeohydrologic records from regional lakes, compiled by Fritz et al. (2000). Moon Lake and Coldwater Lake records represent diatom-inferred salinity of the past millennium; Rice Lake record represents $\mathrm{Mg} / \mathrm{Ca}$ of $\mathrm{C}$. rawsoni.

of Stahle et al. (2000), showing extended sixteenth-century drought over much of the mid-latitude North American interior.

After c. AD 1800, salinity events observed in the Spring Lake record decrease in period, a trend not obvious in the records examined by Fritz et al. (2000). One possible explanation for this apparent change lies in the upcore increase in resolution (inherent in our shell sampling approach) coupled with the probable complexity of interactions between lakes of the Waubay system during periods of water-balance transience (discussed below). However, St George and Nielsen (2002) note decreasing amplitude of precipitation anomalies in southern Manitoba after AD 1800, lending support to the idea of a subtle alteration in NGP climatic variability around that time. Major salinity events of the post-1800 record (e.g., the low $\mathrm{Mg} / \mathrm{Ca}$ event centred on $c$. AD 1890 and the Dust Bowl high$\mathrm{Mg} / \mathrm{Ca}$ event) can be regionally correlated with geochemical evidence from the other palaeohydrologic records shown.

We can also show good correspondence between the post-AD 1650 Spring Lake salinity record and the local tree-ring record of moisture. Figure 8 shows our proposed correlation to the tree-ring-based moisture-supply curve. From the mid-nineteenth century to the present, extremes of moisture supply deduced from the tree-ring record correspond to hydrologic events deduced from ostracode shell chemistry within the standard error of our ${ }^{210} \mathrm{~Pb}$ dating. Between $\mathrm{AD}$ 1650 and 1850 , major events can be correlated with confidence, although chronological discrepancies increase somewhat, reflecting the uncertainty inherent in ${ }^{14} \mathrm{C}$ dates. We believe that this correlation shows $Q$. macrocarpa growth rates and lake salinity responding in near synchrony to closely related climate controls: soil and subsoil moisture availability to plants, and watershed-scale surface and subsurface water balance.

\section{Basin coalescence and hydrological modification}

The response of $C$. rawsoni shell chemistry to the highstand of the 1990s represents an apparent departure from the earlier record analysed. Despite the historically high lake stage and volume achieved in 1999 , the record of $\mathrm{Mg} / \mathrm{Ca}$ maintains a generally upward trend through the most recent samples analysed. These shells date from as recently as 1998, when the volume of Spring Lake had increased by a factor of 2.5 from that at the beginning of the 1990s stage increase (Niehus et al., 1999a).

We hypothesize that the rising-stage control of salinity and $\mathrm{Mg}^{2+} / \mathrm{Ca}^{2+}$ in Spring Lake rests with a complex set of interactions between the waters of Spring, Hillebrands, Waubay and Rush Lakes and Swan Pond, which coalesced into a single interconnected water body in the late 1990s. Table 3 shows that, as these lakes approached coalescence in 1995, they carried a substantial range of dissolved solids. When Spring Lake merged with the Swan and Hillebrands basins, more saline water probably bearing higher $\mathrm{Mg}^{2+} / \mathrm{Ca}^{2+}$ began mixing with Spring Lake (the specific conductance of Spring Lake doubled between 1995 and 1999). Moreover, the introduction of water of higher alkalinity from the Hillebrands/Waubay system probably enhanced precipitation of calcium carbonate from Spring Lake waters, further increasing $\mathrm{Mg}^{2+} / \mathrm{Ca}^{2+}$ during lake mixing.

Over the same period, spill from the merged lake system to down-gradient Bitter Lake, which results in export of solutes and freshening of the Waubay system, was delayed due to the elevation control imposed by artificial barriers (Niehus et al., 1999a). In addition, the sequencing of water exchange between the adjoining lakes, each with its own hydraulically determined salinization trend, has probably been altered by other barriers and conduits (Niehus et al., 1999a). Thus the short-term response of Spring Lake's chemistry is inherently contrary to a simple salinity-dilution model, and may also have changed with hydromodification of the Waubay Lake system. Calculated annual inflows for the period 1993 to 1999 are roughly a tenth of the recent lake-system volume, suggesting that several years of spill and solute export would be required to equilibrate aqueous chemistry to a lake 
highstand. As spill continues, chemically less-evolved inflow will result in decreasing lakewater $\mathrm{Mg}^{2+} / \mathrm{Ca}^{2+}$, leading to decreasing $\mathrm{Mg} / \mathrm{Ca}$ in ostracode calcite.

\section{Highstand frequency and duration}

Overall correspondence with regional late-Holocene geochemical records and agreement with local tree-ring moisture history indicate that the Spring Lake $\mathrm{Mg} / \mathrm{Ca}$ profile is a highly reliable record of the hydrologic status of the Lake Waubay system. The hydrologic complexities described above and the geochemical complications of ostracode shell magnesium uptake (Xia et al., 1997a) discourage quantitative interpretation of aqueous chemistry from shell data. We interpret the geochemical record of the past millennium as providing strong evidence for a cycle of repeated and sustained highstands punctuated by periods of notable drought. Prior to AD 1800, geochemically dilute conditions tended to persist for several decades or more, suggesting a pattern of wet cycles considerably longer than the 1990s highstand. The consistency of $\mathrm{Mg} / \mathrm{Ca}$ maxima achieved during the dilute events centred on AD $1050,1250,1400$ and 1660 suggests that some hydrologic boundary condition, possibly the spill elevation between the Waubay and Bitter Lake basins, was reached and maintained during these periods. The recurrence frequency of these pluvial peaks averages $\sim 140$ years prior to AD 1800; hydrologic transients of the past two centuries appear to have been more frequent, with peak recurrences in the order of 60 years. At the same time, the duration of chemically inferred climate cycles appears to have been considerably longer prior to $A D$ 1800. Thus the 1000 -year lake-geochemical record suggests a recurrence of wet periods averaging 140 years, with four dilute periods interpreted to represent highstands of comparable volume and considerably longer duration than the 1990s event.

The extended duration of the dilute episodes prior to AD 1800 indicates a greater annual probability of highstand conditions than that reflected in the historical record. Approximately 300 years of the ostracode record appears to reflect dilute water-chemistry conditions, suggesting an annual probability of high lake-stand conditions around 0.3 . This result contrasts with the stochastic water-balance modelling of Niehus et al. (1999a), which suggest lower probabilities and shorter duration of highstand conditions, based on analysis of instrumental lake-stage and meteorological data.

\section{Conclusions}

Wet and dry periods indicated by the tree-ring chronology closely match those indicated by ostracode shell chemistry. The long-term highstand frequency of 163 years derived from the tree-ring chronology over a 325 -year record was similar to the approximate 140-year frequency derived from the lake-sediment record for a 1000 -year period. The prolonged dilute episodes (century length) in Spring Lake prior to AD 1800 indicate a higher annual probability of highstand conditions than during the period of historical record. Approximately 300 years of the ostracode record appear to reflect dilute water-chemistry conditions, suggesting an annual probability of high lake levels of approximately 0.3 . Neither generally low lake levels occurring since European settlement (but before the recent flooding) nor the post-1930s pattern of steadily increasing water availability and favourableness for tree growth are typical of the long-term record. Analyses based on available weather and lake stage records from this period (Niehus et al., 1999a; 1999b) may underestimate the long-term probability and duration of highstand conditions.
The outlet from Bitter Lake, the terminal lake in the Waubay Lake system, appears not to have functioned since the start of the Holocene. Thus, hydrologic controls have kept this lake system often nearly full of water but rarely if ever overflowing. One control mechanism could be the increasing evaporation that occurs as Waubay and Bitter Lakes expand in area during filling.

Ultimately, it is difficult to say whether the prolonged high water conditions seen repeatedly in the lake-sediment record reached 1990s flood proportions or only approached them. The extreme nature of recent flooding may have been amplified relative to pre-European conditions by past wetland drainage, greater groundwater recharge and runoff from agricultural lands in the basin, and by the blocking or slowing of channel flow by roadbeds. Although highstand conditions in the basin were not unusual in the past, human influence may be contributing to the severity of contemporary flooding.

\section{Acknowledgements}

Craig Milewski of the East Dakota Water Development District in Brookings assisted in the tree coring project by locating and sampling old trees and preparing the cores for measurement and analysis. Mike Scott of the USGS's Midcontinent Ecological Science Center in Fort Collins provided laboratory space and equipment for core measurement. Peter Brown of the Rocky Mountain Tree-Ring Laboratory (Fort Collins) crossdated the Fort and modern cores, conducted statistical analyses and constructed graphs. Dave Greenlee of EROS Data Center quantified lake area from LANDSAT imagery. Bruce Millett used GIS to calculate historic lake areas, and A.H. MacLeod made a thorough search of relevant literature for this study and assisted in the analysis of aerial photography and topographic maps. Becky Teed (LRC) performed LOI analyses and did the pollen sample preparation. Pollen analysis was done by Barb Hansen (LRC), ${ }^{210} \mathrm{~Pb}$ was analysed by Kelly Thommes (SCWRS), and ostracode identifications were confirmed by Rick Forester, USGS (Denver). Douglas Leschisin, Refuge Manager, allowed collection of tree cores from the Waubay Lake National Wildlife Refuge. Funding was from the Federal Emergency Management Agency through the US Geological Survey (Rapid City and Huron, SD offices).

\section{References}

Alley, W.A. 1984: The Palmer drought severity index; limitations and assumptions. Journal of Applied Meteorology 23, 1100-109.

Appleby, P.G. and Oldfield, F. 1978: The calculation of lead-210 dates assuming a constant rate of supply of unsupported ${ }^{210} \mathrm{~Pb}$ to the sediment. Catena 5, 1-8.

Bennett, C.E. 1878: Unpublished letter to the Adjutant General of the Army. United States War Department Manuscript. Washington, DC: National Archives.

Binford, M.W. 1990: Calculation and uncertainty analysis of ${ }^{210} \mathrm{~Pb}$ dates for PIRLA project lake sediment cores. Journal of Paleolimnology 3, 253-67.

Bryson, R.A. and Hare, F.K. 1974: The climates of North America. In Bryson, R.A. and F.K. Hare, Climates of North America, New York: Elsevier, 1-47.

Chivas, A.R., De Deckker, P. and Shelley, J.M.G. 1986: Magnesium content of non-marine ostracod shells: a new palaeosalinometer and palaeothermometer. Paleogeography, Paleoclimatology, Paleoecology 54, 43-61.

Cook, E.R., Meko, D.M., Stahle, D.M. and Cleaveland, M.K. 1996: Tree-ring reconstructions of past drought across the coterminous United States: tests of a regression method and calibration/verification 
results. In Dean, J.S., Meko, D.M. and Swetman, T.W., Tree ring, environment, and humanity, Tucson: Radiocarbon, 155-69.

Dean, W.E. Jr 1974: Determination of carbonate and organic matter in calcareous sediments and sedimentary rocks by loss on ignition: comparison with other methods. Journal of Sedimentary Petrology 44, 242-48.

De Deckker, P., Chivas, A.R. and Shelley, J.M.G. 1999: Uptake of $\mathrm{Mg}$ and $\mathrm{Sr}$ in the euryhaline ostracod Cyprideis determined from in vitro experiments. Paleogeography, Paleoclimatology, Paleoecology 148, 105-16.

Eakins, J.D. and Morrison, R.T. 1978: A new procedure for the determination of lead-210 in lake and marine sediments. International Journal of Applied Radiation and Isotopes 29, 531-36.

Engstrom, D.R. and Nelson, S. 1991: Paleosalinity from trace metals in fossil ostracodes compared with observational records at Devils Lake, N. Dakota. Paleogeography, Paleoclimatology, Paleoecology 83, 295-312.

Faegri, K. and Iversen, J. 1975: Textbook of pollen analysis. New York: Hafner Press, 295 pp.

Fritz, S.C., Engstrom, D.R. and Haskell, B.J. 1994: 'Little Ice Age' aridity in the North American Great Plains: a high-resolution reconstruction of salinity fluctuations from Devils Lake, North Dakota, USA. The Holocene 4, 69-73.

Fritz, S.C., Ito, E., Yu, Z., Laird, K.R. and Engstrom, D.R. 2000: Hydrologic variation in the northern Great Plains during the last two millennia. Quaternary Research 53, 175-84.

Haskell, B.J., Engstrom, D.R. and Fritz, S.C. 1996: Late Quaternary paleohydrology in the North American Great Plains inferred from the geochemistry of endogenic carbonates and fossil ostracodes from Devils Lake, North Dakota, USA. Paleogeography, Paleoclimatology, Paleoecology 124, 179-93.

Holmes, J.A. 1996: Trace-element and stable-isotope geochemistry of non-marine ostracod shells in Quaternary palaeoenvironmental reconstruction. Journal of Paleolimnology 15, 223-35.

Jacobson, H.A. and Engstrom, D.R. 1989: Resolving the chronology of recent lake sediments: an example from Devils Lake, North Dakota. Journal of Paleolimnology 2, 81-98.

Keyantash, J. and Dracup, J.A. 2002: The quantification of drought: an evaluation of drought indices. Bulletin of the American Meterological Society 83, 1167-80.

Laird, K.R., Fritz, S.C. and Cumming, B.F. 1998: A diatom-based reconstruction of drought intensity, duration, and frequency from Moon Lake, North Dakota: a sub-decadal record of the last 2300 years. Journal of Paleolimnology 19, 161-79.

Laird, K.R., Fritz, S.C., Maasch, K.A. and Cummings, B.F. 1996: Greater drought intensity and frequency before AD 1200 in the northern Great Plains, USA. Nature 384, 552-54.

Müller, G., Irion, G. and Förstner, U. 1972: Formation and diagenesis of inorganic $\mathrm{Ca}-\mathrm{Mg}$ carbonates in the lacustrine environment. Naturwissen 59, 158-64.

Niehus, C.A., Vecchia, A.V. and Thompson, R.F. 1999a: Lake-level frequency analysis for the Waubay Lakes Chain, northeastern South Dakota. US Geological Survey Water-Resources Investigations Report 99-4122, 166 pp.

1999b: Supplement to Water Resources Investigations Report 99-4122. Lake-level frequency analysis for the Waubay Lakes Chain, northeastern South Dakota. US Geological Survey Water-Resources Investigations Report 99-4251, 24 pp.

Northern Great Plains Water Resources Research Center (NGPWRRC) 1999: History of inundation 1992-1998; Day County and Waubay Lakes Chain; Northeastern South Dakota. Task 1 Report to FEMA. Brookings, SD: South Dakota State University.

Rothrock, E.P. 1935: Geology and water resources of Day County, South Dakota. South Dakota State Geological Survey Report of Investigations no. $25,30 \mathrm{pp}$.

Sieg, C.H. and Meko, D. 1995: Tree-ring collections in the northern Great Plains in 1991 and 1992. Appendix to Final Project Report to the National Science Foundation for Grants ATM-9016901 and ATM-9017155.

Smith, A.J. 1993: Lacustrine ostracodes as hydrochemical indicators in lakes of the north-central United States. Journal of Paleolimnology 8, 121-34.

Stahle, D.W., Cook, E.R., Cleaveland, M.K., Therrell, M.D., Meko, D.M., Grissino-Mayer, H.D., Watson, E. and Luckman, B.H. 2000: Tree-ring data document $16^{\text {th }}$ century megadrought over North America. Eos 81, 121, 125.

St. George, S. and Nielsen, E. 2002: Hydroclimatic change in southern Manitoba since A.D. 1409 inferred from tree rings. Quaternary Research 58, 103-11.

Stokes, M.A. and Smiley, T.L. 1996: An introduction to tree-ring dating. Tucson: University of Arizona Press, $73 \mathrm{pp}$.

Stuiver, M. and Reimer, P.J. 1993: Extended ${ }^{14} \mathrm{C}$ database and revised CALIB radiocarbon calibration program. Radiocarbon 35, 215-30.

Stuiver, M., Reimer, P.J., Bard, E., Beck, J.W., Burr, G.S., Hughen, K.A., Kromer, B., McCormac, F.G., van der Plicht, J. and Spurk. M. 1998: INTCAL98 radiocarbon age calibration 24,000 - 0 cal. BP. Radiocarbon 40, 1041-83.

Wansard, G., De Deckker, P. and Julià, R. 1998: Variability in ostracod partition coefficients $\mathrm{D}(\mathrm{Sr})$ and $\mathrm{D}(\mathrm{Mg})$. Implications for lacustrine palaeoenvironmental reconstructions. Chemical Geology 146, 39-54.

Wiche, G., Lent, R.M., Rannie, W.F. and Vecchia, A.V. 1997: A history of lake-level fluctuations for Devils Lake, North Dakota, since the early 1800s. Proceedings of the $89^{\text {th }}$ Annual Meeting of the North Dakota Academy of Science, Grand Forks, 34-39.

Winter, T.C. and Rosenberry, D. 1998: Hydrology of prairie pothole wetlands during drought and deluge: a 17-year study of the Cottonwood Lake wetland complex in North Dakota in the perspective of longer term measured and proxy hydrological records. Climatic Change 40, 189-210.

Xia, J., Engstrom, D.R. and Ito, E. 1997a: Geochemistry of ostracode calcite: Part 2. The effects of lake-water chemistry and seasonal temperature variation on Candona rawsoni. Geochimica et Cosmochimica Acta 61, 383-91.

Xia, J., Haskell, B.J., Engstrom, D.R. and Ito, E. 1997b: Holocene climate reconstructions from tandem trace-element and stable-isotope composition of ostracodes from Coldwater Lake, North Dakota, U.S.A. Journal of Paleolimnology 17, 85-100.

Yu, Z., Ito, E., Engstrom, D.R. and Fritz, S.C. 2002: A 2100year decadal-resolution trace-element and stable-isotope record from Rice Lake in the northern Great Plains, USA. The Holocene 12, 605-17. 